\title{
KAJIAN ILMIAH PENGARUH AIR REBUSAN BUAH PINANG TERHADAP PENURUNAN KADAR GULA DARAH PADA PENDERITA DIABETES
}

\author{
Dina Muslimah ${ }^{1^{*}}$ \\ ${ }^{1}$ Jurusan Kimia, FMIPA, Universitas Negeri Padang, Indonesia \\ *E-mail : dinamuslimah625@gmail.com
}

\begin{abstract}
Abstrak. Kajian ini bertujuan untuk mengetahui pengaruh air rebusan buah pinang terhadap penurunan kadar gula darah bagi penderita diabetes melitus. Metode yang dilakukan adalah eksperimen dan uji aktivitas katalitik langsung pada penderita diabetes. Tahapan pertama yang dilakukan adalah pembuatan air rebusan dari buah pinang. Uji aktivitas langsung dilakukan dengan variasi jumlah buah pinang yang diminum satu gelas dalam sehari selama tiga hari. Hasil eksperimen membuktikan bahwa air rebusan buah pinang dapat menurunkan kadar gula dalam darah. Kondisi optimum air rebusan buah pinang tercapai pada $162 \mathrm{mg} / \mathrm{dL}$. Penurunan kadar gula darah ini diduga karena aktivitas katalitik air rebusan buah pinang ternadap sel darah.
\end{abstract}

Kata Kunci: katalitik, buah pinang, diabetes mellitus, kadar gula darah, alkaloid.

\section{Pendahuluan}

Reaksi kimia [1] merupakan suatu reaksi yang sangat penting dalam kehidupan. Reaksi kimia [2] merupakan suatu proses yang menghasilkan suatu perubahan baru, termasuk dalam tubuh kita. Didalam tubuh, reaksi [3] terus terjadi. Setiap saat sel [4] diperbaharui dengan reaksi. Katalitik [5] sangat berperan dalam suatu reaksi. Katalis [6] akan mempercepat terbentuknya suatu produk dalam suatu reaksi tanpa ikut bereaksi. Katalis yang baik untuk tubuh kita adalah katalis herbal.

Katalis herbal umumnya terdapat pada tumbuh-tumbuhan [7]. Indonesia memiliki keanekaragaman jenis tanaman [8]. Ribuan jenis tumbuhan [9] telah dimanfaatkan masyarakat sebagai pengobatan herbal [10], salah satunya adalah pinang [11]. 
Tanaman pinang (Areca catechu) [12] memiliki batang yang lurus dan tinggi dengan buah yang berbentuk lonjong. Umumnya pinang ditanam oleh masyarakat sebagai pembatas kebun.

Sejak ratusan tahun yang lalu pinang telah dimanfaatkan oleh nenek moyang sebagai bahan ramuan untuk menyirih [13], sampai sekarang budaya menyirih telah menjadi kebiasaan yang turun temurun. Di Indonesia pemanfaatan buah pinang masih sangat minim, masih banyak masyarakat yang belum mengetahui manfaat lain dari buah pinang. Buah pinang dapat dijadikan obat- obatan [14] [15]. Pinang dapat mengatasi berbagai penyakit [16], salah satunya adalah diabetes melitus [17].

Diabetes mellitus [18] atau yang lebih dikenal dengan kencing manis merupakan suatu penyakit yang ditandai dengan kadar gula darah [19] yang melebihi batas normal akibat kekurangan insulin [20]. Faktor yang menyebabkan diabetes diantaranya genetik, gizi [21] makanan, gaya hidup, dan obesitas [22]. Kadar gula darah yang tinggi akan memicu komplikasi.

Setiap tahunnya angka kematian penderita diabetes melitus semakin meningkat akibat komplikasi. Melihat banyaknya penderita diabetes, penelitian telah banyak dilakukan pada beberapa tumbuh-tumbuhan tertentu untuk mengatasi diabetes salah satunya yaitu dengan air rebusan [23] buah pinang. Dari hasil penelitian yang dilakukan terhadap salah satu wanita penderita diabetes melitus [24], ternyata setiap minum satu gelas air rebusan buah pinang $(220 \mathrm{ml})$ dapat menurunkan kadar gula darah normal rata-rata sebesar $93 \mathrm{mg} / \mathrm{dL}$. 
Berdasarkan dari kejadian ini, penulis melakukan eksperimen yang bertujuan untuk mengetahui apakah pengaruh [25] air rebusan buah pinang dapat menurunan kadar gula darah bagi penderita diabetes.

\section{Metode}

Alat dan bahan

Peralatan yang digunakan untuk membuat rebusan buah pinang yaitu pisau (Santoku), panci (maspion group), kompor gas (Rinnai), gelas (royalex), satu set alat cek gula darah (Easy Touch GCU), kamera (Samsung Galaxy J2). Bahan yang digunakan yaitu buah pinang (diambil dari perkebunan didaerah Pagar Dewa, Kabupaten Kaur, Bengkulu), $600 \mathrm{ml}$ air (Le Mineral).

a. Penyiapan sampel

Sampel barupa buah pinang yang diambil dari lokasi perkebunan di Pagar Dewa, kabupaten Kaur, provinsi Bengkulu.

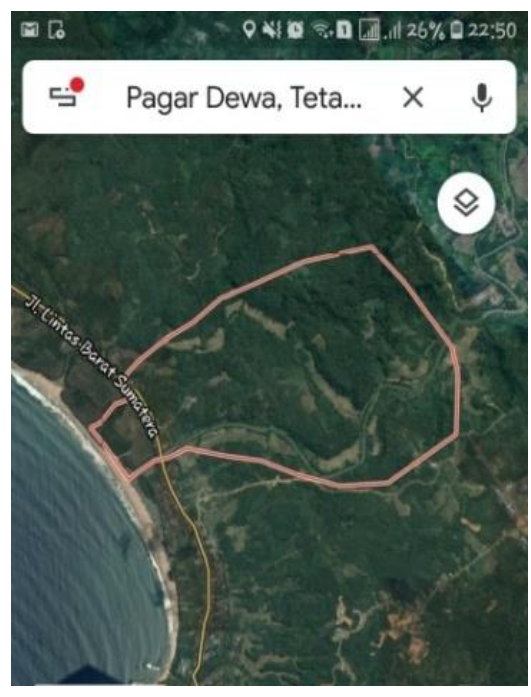

Gambar 1. Lokasi pengambilan buah pinang 


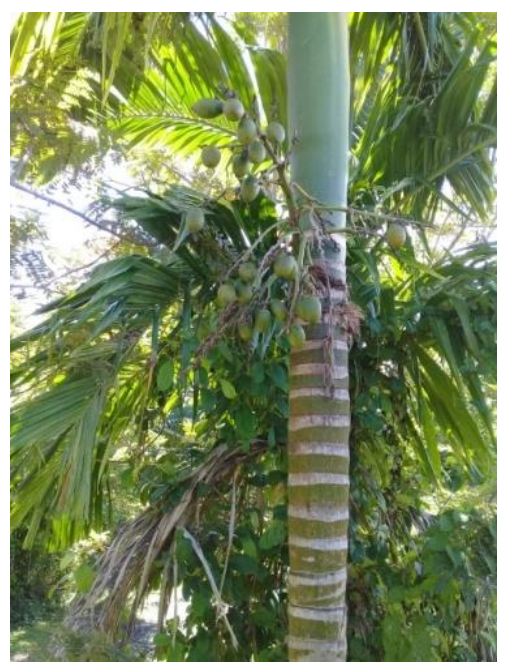

Gambar 2. Tanaman Pinang

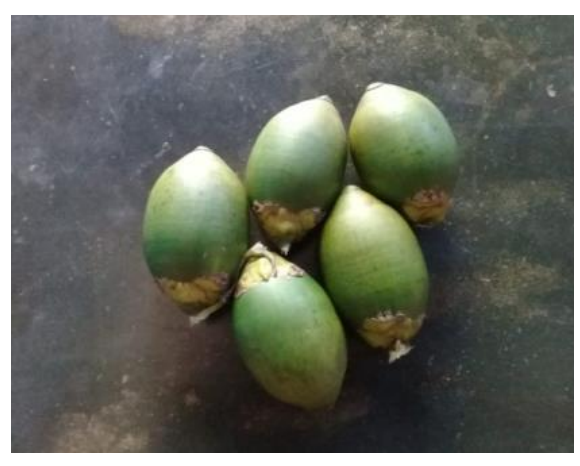

Gambar 3. Buah Pinang (5 buah)

\section{b. Pembuatan}

Untuk membuat air rebusan pinang digunakan 5 buah pinang pada hari pertama dan 3 buah pada hari kedua dan hari ketiga. Pinang yang digunakan berwarna hijau tua. Kemudian buah tersebut dicuci dengan air bersih. Kemudian buah pinang dibelah menjadi dua bagian menggunakan pisau. Selanjutnya pinang yang telah dibelah direbus dengan air mineral sebanyak $600 \mathrm{ml}$ sampai mendidih hingga tersisa satu gelas. Setelah itu air rebusan dimasukkan ke dalam gelas. 


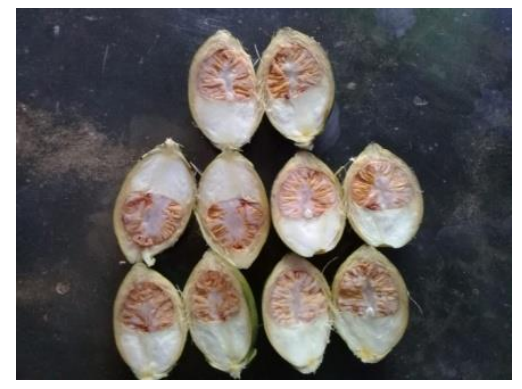

Gamabar 4. Buah pinang yang telah dibelah

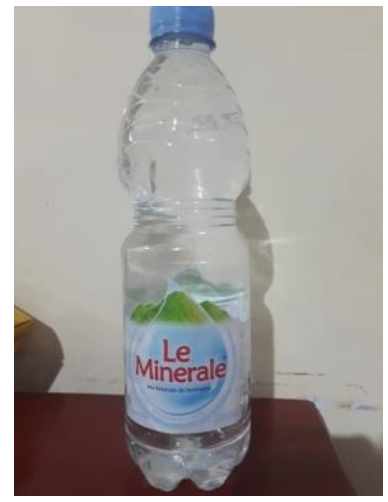

Gambar 5. Air mineral (600ml)

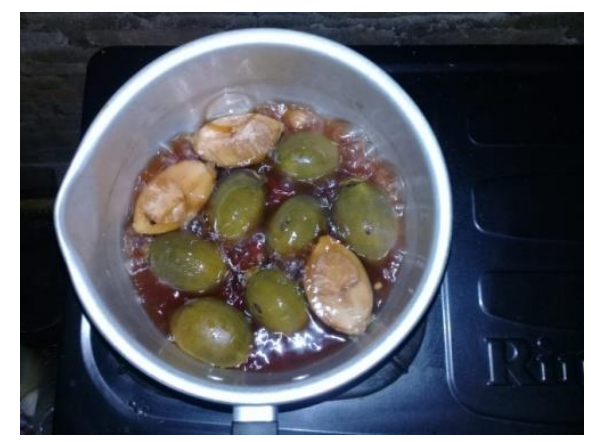

Gambar 6. Pinang direbus sampai berwarna merah kecoklatan

c. Pengujian

Air rebusan yang telah diuji cobakan pada wanita penderita diabetes (47 tahun) yang memiliki kadar gula $440 \mathrm{mg} / \mathrm{dL}$ dengan variasi 5 buah pinang dan 3 buah pinang 
selama tiga hari. Hasil eksperimen telah ditanyakan kepada penderita diabetes bahwa pada hari ketiga kadar gula darah mendekati angka normal yaitu $162 \mathrm{mg} / \mathrm{dL}$.

Sebelum meminum air rebusan buah pinang, sebaiknya mengecek kadar gula darah untuk mengetahui penurunan kadar gula darah. Berikut hasil pengecekan kadar gula sebelum mengonsumsi air rebusan pinang menggunakan alat cek gula darah (Easy Touch:GCU).

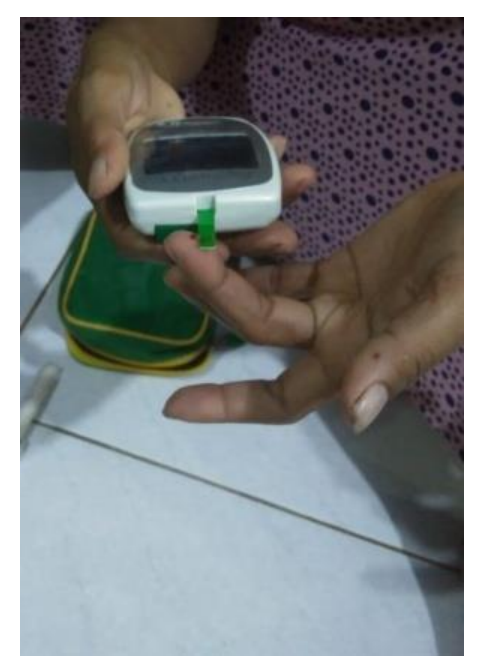

Gambar 7. Proses pengecekan

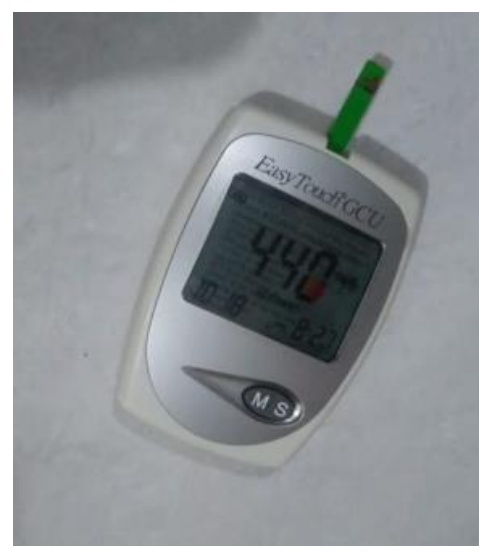

Gambar 8. Angka menunjukan kadar gula darah 
Metode ini dapat dibuat secara diagram alir sebagai berikut:

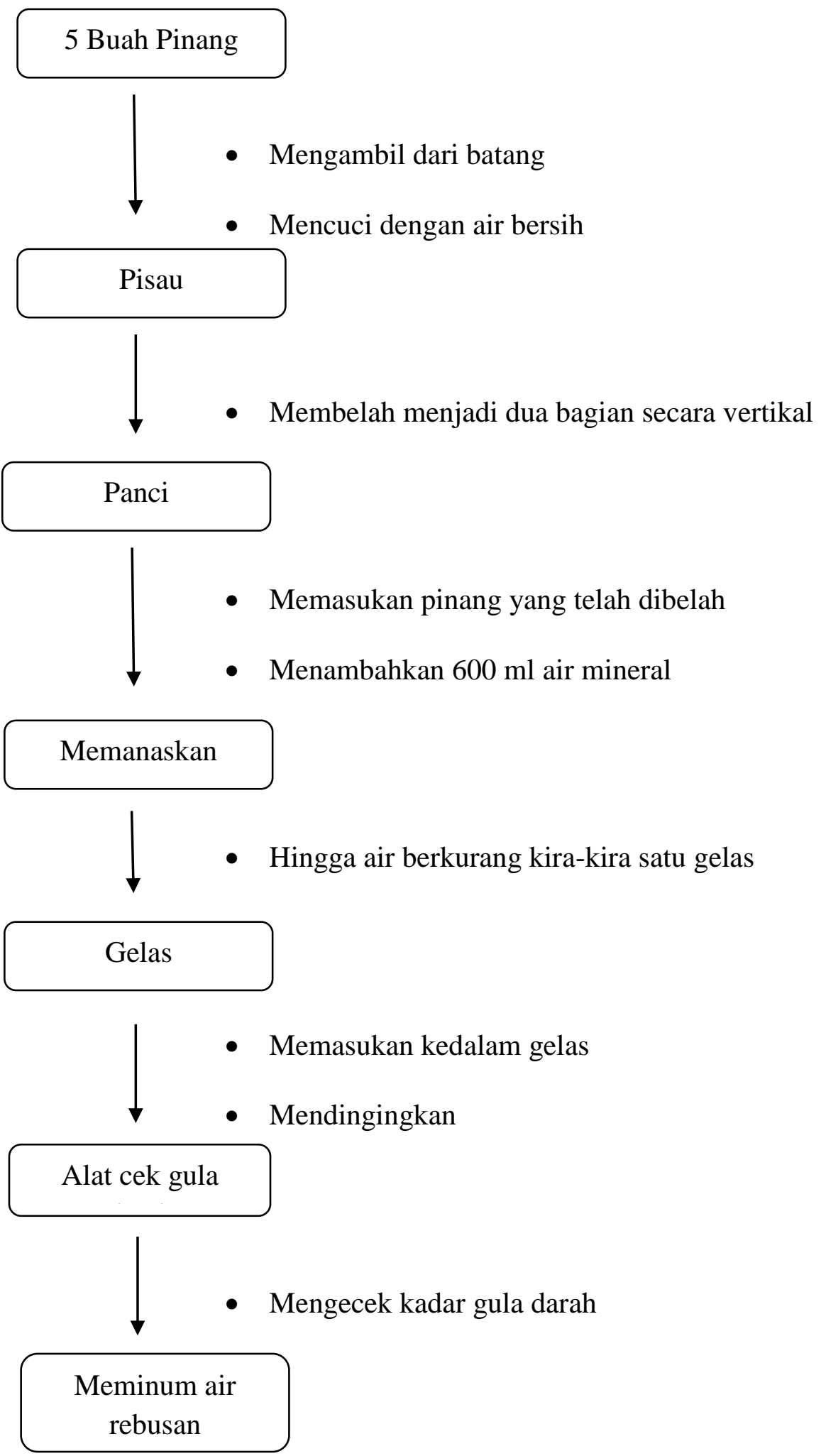


3. Hasil dan Pembahasan

a. Hasil pembuatan

Hasil pembutan air rebusan buah pinang diperoleh sebanyak satu gelas $(220 \mathrm{ml})$. pembuatan 5 buah pinang dengan $600 \mathrm{ml}$ air mineral .

Hal ini dapat dilihat dari gambar berikut:

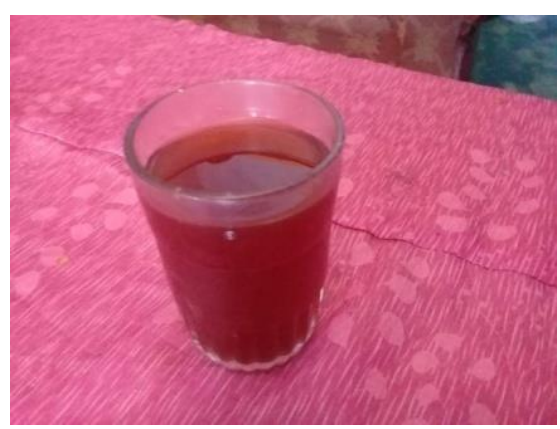

Gambar 9. Air rebusan siap diminum

b. Hasil uji coba

Pengujian dilakukan terhadap penderita diabetes mellitus yang memiliki kadar gula darah $440 \mathrm{mg} / \mathrm{dL}$ ternyata terbukti dapat menurunkan kadar gula darah setelah 3 hari. Penjelasan dapat dilihat pada tabel:

\begin{tabular}{|ccc|}
\hline Hari & Jumlah pinang & $\begin{array}{c}\text { Kadar gula } \\
\text { ke }-\end{array}$ \\
\hline $\mathbf{1}$ & 5 buah & 345 \\
\hline $\mathbf{2}$ & 3 buah & 253 \\
\hline $\mathbf{3}$ & 3 buah & 162 \\
\hline
\end{tabular}


Pembahasan

a. Pembuatan

Dalam melakukan pembuatan air rebusan pinang yang digunakan untuk menurunkan kadar gula darah terdapat kendala dalam mencari buah pinang, dimana buah pinang umumnya ditanam warga sebagai pembatas kebun. Sehingga buah pinang dapat ditemukan didaerah perkebunan warga desa Pagar Dewa, Kabupaten Kaur, Provinsi Bengkulu. Kendala lainnya yaitu batang pinang cukup tinggi sehingga menyulitkan untuk mengambil buah pinang. Dalam memilih buah pinang yang akan digunakan harus berwarna hijau tua atau mulai menguning. Karena dalam keadaan ini buah sudah baik digunakan.

Dalam proses pembuatan air rebusan buah pinang ini cukup mudah, dan dapat diterapkan. Karena proses pembuatan sama seperti pembuatan obat herbal air rebusan pada umumnya. Dalam pengolahan buah pinang harus dalam keadaan bersih agar terhindar dari kotoran. Buah pinang yang digunakan pada hari pertama sebanyak 5 buah, karena saat kadar gula darah sangat tinggi air rebusan yang dikonsumsi harus lebih pekat. Untuk hari kedua dan ketiga digunakan buah pinang sebanyak 3 buah karena kadar gula darah sudah tidak terlalu tinggi. Jika masih digunakan dengan jumalah yang sama seperti hari pertama, dikhawatirkan kadar gula dara akan turun sangat drastis. Selanjutnya dipotong menjadi dua bagian secara vertikal. Buah pinang yang telah dibelah direbus menggunakan air sebanyak $600 \mathrm{ml}$ sampai air rebusan mendidih dan berwarna merah kecoklatan. Pemanasan dihentikan saat air rebusan kira-kira tersisa satu gelas $(220 \mathrm{ml})$. Air rebusan dimasukan ke dalam gelas. Sambil mendinginkan air rebusan, sebaiknya penderita diabetes mellitus mengecek kadar gula 
darahnya untuk mengetahui berapa angka perubahan kadar gula darah sebelum dan sesudah mengonsumsi air rebusan pinang.

b. Uji coba

Eksperimen dilakukan terhadap seorang wanita ( 47 tahun) penderita diabetes memiliki kadar gula darah $440 \mathrm{mg} / \mathrm{dL}$. Pada hari pertama, setelah meminum air rebusan pinang sebanyak 1 gelas dengan jumlah pinang 5 buah ternyata dapat menurunkan kadar gula darah sebanyak $95 \mathrm{mg} / \mathrm{dL}$. Pada hari kedua digunakan volume air yang sama dengan buah pinang sebanyak 3 dapat menurunkan kadar gula darah sebanyak $93 \mathrm{mg} / \mathrm{dL}$. Pada hari ketiga digunakan variasi yang sama dengan hari kedua dan didapatkan penurunan kadar gula darah sebanyak $91 \mathrm{mg} / \mathrm{dL}$. Berdasarkan data dari eksperimen dan uji aktivitas langsung terhadap seorang wanita penderita diabetes dapat membuktikan bahwa air rebusan buah pinang dapat menurunkan kadar gula darah.

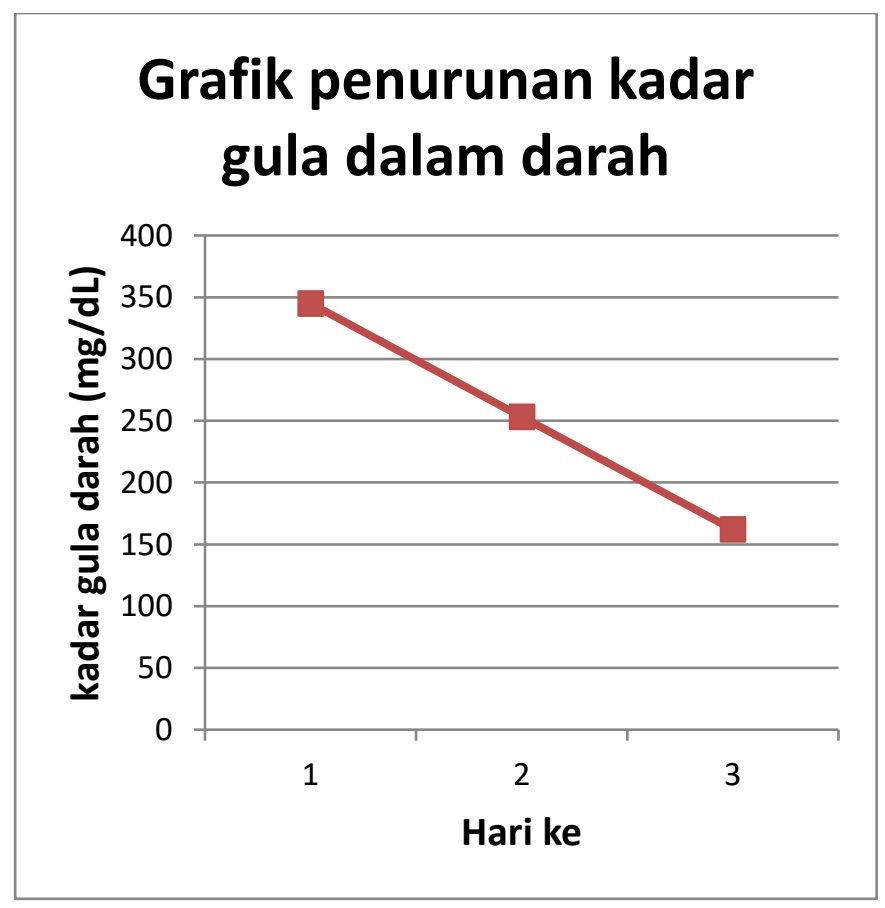


c. Interaksi

Dari hasil eksperimen menunjukkan bahwa setelah meminum [26] air rebusan pinang terjadi penurunan [27] kadar gula darah pada penderita diabetes. Hal ini dipengaruhi karena [28] buah pinang mengandung alkaloid [29]. Alkaloid dapat menghambat kerja enzim [30] alfa-glukosidase [31]. Enzim alfa-glukosidase merupakan enzim yang dapat mengubah polisakarida menjadi monosakarida. Glukosa merupakan kelompok dari monosakarida. Dengan adanya senyawa alkaloid dapat menghambat kerja enzim alfa-glukosidase di usus sehingga reaksi penguraian [32] polisakarida menjadi monosakarida akan terhalang. Oleh karena itu glukosa dilepaskan lebih lambat ke dalam darah sehingga kadar gula darah tinggi dapat terhindari.

Selain itu senyawa [33] yang terkandung didalam buah pinang yang dapat merintangi penyerapan glukosa dalam usus yaitu tanin [34]. Senyawa tanin memiliki fungsi sebagai astringen yang mampu mengendapkan protein [35] selaput lendir dipermukaan usus dan akan membentuk suatu lapisan yang dapat melindungi usus, sehingga menghambat penyerapan glukosa dalam darah.

4. Kesimpulan

Berdasarkan hasil eksperimen dan uji aktivitas langsung yang telah dilakukan, maka dapat diambil kesimpulan sebagai berikut:

a. Air rebusan buah pinang (Areca catechu) dibuat dari 5 buah pinang dengan $600 \mathrm{ml}$ air mineral diperoleh 1 gelas $(220 \mathrm{ml})$ air rebusan buah pinang.

b. Air rebusan buah pinang yangdapat menurunkan kadar gula darah rata-rata $93 \mathrm{mg} / \mathrm{dL}$ per gelas. 
c. Ai rebusan buah pinang mengandung alkaloid yang dapat menghambat enzim alfaglukosidase sehingga menurunkan kadar gula darah.

\section{Referensi}

[1] Hidayani, T. (2018) “GRAFTING POLIPROPILENA DENGAN MALEAT ANHIDRIDA SEBAGAI PENGIKAT SILANG DENGAN INISIATOR BENZOIL PEROKSIDA", EKSAKTA: Berkala Ilmiah Bidang MIPA, 19(1), pp. 56-62. doi: 10.24036/eksakta/vol19-iss1/127.

[2] Ruswandi, R. (2018) "Determination of Fructose Content resulted by Inulin Hydrolysis with DNS as Oxidizer”, EKSAKTA: Berkala Ilmiah Bidang MIPA, 19(1), pp. 14-23. doi: 10.24036/eksakta/vol19-iss1/102.

[3] M., Sanjaya, H., \& Zainul, R. (2018, August 11). Characterization of napa soil and adsorption of $\mathrm{Pb}$ (II) from aqueous solutions using on column method. https://doi.org/10.31227/osf.io/t8fh9

[4] Yulis, R., Zainul, R., \& M. (2018, December 10). DESAIN DAN KARAKTERISASI SEL SURYA SISTEM ELEKTRODA TEMBAGA (I) OKSIDA (Cu2O/Al) MODEL PIPA PADA LARUTAN NATRIUM SULFAT (Na2SO4). https://doi.org/10.31227/osf.io/m43js

[5] Uhi, Harry Triely. 2006. Perbandingan Suplemen Katalitik dengan Bungkil Kedelai terhadap Penampilan Domba (Comparative of Catalytic Supplement and Soybean Meal on Performance of Sheep). Jurnal Ilmu Ternak. Vol 6, No 1

[6] Sanjaya, H. (2018) "DEGRADASI METIL VIOLET MENGGUNAKAN KATALIS ZnO-TiO2 SECARA FOTOSONOLISIS”, EKSAKTA: Berkala Ilmiah Bidang MIPA, 19(1), pp. 91-99. doi: 10.24036/eksakta/vol19-iss1/131. 
[7] Dinata, M. and Soehardi, F. (2018) "Factor Analysis of Physics Chemistry Waters that Affects Damage Safety Cliff on the Outskirts of River Siak", EKSAKTA: Berkala Ilmiah Bidang MIPA, 19(2), pp. 46-49. doi: 10.24036/eksakta/vol19-iss2/143.

[8] Warlinda, Y. A., \& Zainul, R. (2019, January 29). Asam Posfat (H3PO4): Ionic Transformation of Phosphoric Acid in Aqueous Solution. https://doi.org/10.31227/osf.io/s3y8v

[9] Putri, D., Fifendy, M. and putri, M. (2018) “DIVERSITAS BAKTERI ENDOFIT PADA DAUN MUDA DAN TUA TUMBUHAN ANDALEH (Morus macroura miq.)", EKSAKTA: Berkala Ilmiah Bidang MIPA, 19(1), pp. 125-130. doi: 10.24036/eksakta/vol19-iss1/122.

[10] Huda, N. (2017) "PENGARUH EKSTRAK SAMBILOTO (Andrographis paniculata Nees.) TERHADAP SIKLUS ESTRUS MENCIT (Mus musculus L. Swiss Webster)", EKSAKTA: Berkala Ilmiah Bidang MIPA, 18(02), pp. 69-76. doi: 10.24036/eksakta/vol18-iss02/55.

[11] Gede Krisna, Udiana, Yuda Sujana, Kadek, A.M, Putu Yohana. 2009. AKTIVITAS MIKROBIAL EKSTRAK BUAH PINANG (ARECA CATECHU) TERHADAP BAKTERI PEMBENTUK ASAM YANG DIISOLASI DARI TONGGA MULUT. IPTEKMA. Volume 1 No.1

[12] Akmal, Muslim, Mahdi, Chanif. 2010. Peningkatan Konsentrasi Testosteron pada Tikus Akibat Paparan Ekstrak Air Biji Pinang. Jurnal Veteriner. Vol 11, No 4 [13] Feronika, N. I., \& Zainul, R. (2018, November 19). Kalium Permanganat: Termodinamika Mengenai Transport Ionik dalam Air. https://doi.org/10.31227/osf.io/g6eyk

[14] Bogoriani, N. W. 2010. EKSTRAKSI ZAT WARNA ALAMI CAMPURAN BIJI PINANG, DAUN SIRIH, GAMBIR DAN PENGARUH PENAMBAHAN KMnO4 TERHADAP PEWARNAAN KAYU JENIS ALBASIA. Journal of Chemistry. Vol. 4, No. 2 
[15] Prihatini, R. (2017) “PEMANFAATAN AIR KELAPA UNTUK MENINGKATKAN PERTUMBUHAN AKAR STEK TUNAS AKSILAR Andrographis paniculata Nees", EKSAKTA: Berkala Ilmiah Bidang MIPA, 18(02), pp. 62-68. doi: 10.24036/eksakta/vol18-iss02/54.

[16] Susilaningrum, D. (2017) "PEMODELAN REGRESI LOGISTIK PADA FAKTOR YANG MEMPENGARUHI PHBS PADA RUMAH TANGGA PENDERITA TBC DI PESISIR SURABAYA”, EKSAKTA: Berkala Ilmiah Bidang MIPA, 18(02), pp. 121-128. doi: 10.24036/eksakta/vol18-iss02/65.

[17] Iryani, I., Iswendi, I. and Katrina, I. T. (2017) “UJI AKTIVITAS ANTI DIABETES MELLITUS SENYAWA METABOLIT SEKUNDER FRAKSI AIR DARI BERAS KETAN HITAM ( Oryza satival. Var glutinosa) PADA MENCIT PUTIH”, EKSAKTA: Berkala Ilmiah Bidang MIPA, 18(01), pp. 54-60. doi: 10.24036/eksakta/vol18-iss01/17.

[18] Sumarmin, R. (2018) "Pengaruh Ekstrak Kulit Buah Manggis (Garcinia mangostana L.) terhadap Histologis Pankreas Mencit (Mus musculus L. Swiss Webster) yang Diinduksi Sukrosa”, EKSAKTA: Berkala Ilmiah Bidang MIPA, 19(1), pp. 100-112. doi: 10.24036/eksakta/vol19-iss 1/123.

[19] Rizki Saputra, M. and Sumarmin, R. (2018) "PENGARUH EKSTRAK DAUN SIRIH MERAH (Piper crocatum Ruiz \& Pav.) TERHADAP GLUKOSA DARAH MENCIT (Mus musculus L.) JANTAN YANG DIINDUKSI SUKROSA", EKSAKTA: Berkala Ilmiah Bidang MIPA, 19(1), pp. 43-55. doi: 10.24036/eksakta/vol19-iss1/124.

[20] Ridwan, Muhammad, Gotera, Wira. 2009. PENGARUH INSULIN TERHADAP FUNGSI KARDIOVASKULAR. Journal of internal medicine. Vol. 10, No. 2

[21] Rahmi H.G, I. (2017) “TELAAH FAKTOR-FAKTOR YANG MEMPENGARUHI STATUS GIZI BALITA DI KOTA PADANG BERDASARKAN BERAT BADAN PER TINGGI BADAN MENGGUNAKAN 
METODE CART”, EKSAKTA: Berkala Ilmiah Bidang MIPA, 18(02), pp. 86-99. doi: 10.24036/eksakta/vol18-iss02/59.

[22] Dewi, Mira. 2007. RESISTENSI INSULIN TERKAIT OBESITAS:

MEKANISME ENDOKRIN DAN INTRINSIK SEL. Jurnal Gizi dan Pangan. Vol 2, No 2

[23] Samah, S. (2017) “KARAKTERISASI PLASTIK BIODEGRADABEL DARI LDPE-g-MA DAN PATI TANDAN KOSONG SAWIT”, EKSAKTA: Berkala Ilmiah Bidang MIPA, 18(02), pp. 30-38. doi: 10.24036/eksakta/vol18-iss02/48 [24] Mona, Eva, Bintanah, Sufiati, Astuti, Rahayu. 2012. Hubungan Frekuensi Pemberian Konsultasi Gizi dengan Kepatuhan Diit Serta Kadar Gula Darah Penderita Diabetes Mellitus Tipe II Rawat Jalan di RS Tugurejo Semarang. Jurnal Gizi. Vol 1, No 1

[25] Zainul, R., Effendi, J., \& M. (2018, December 10). Phototransformation of Linear Alkylbenzene Sulphonate (LAS) Surfactant Using ZnO-CuO Composite Photocatalyst.https://doi.org/10.31227/osf.io/fec28

[26] Sofyanita, S. and Octaria, Z. (2018) "Fenthion Compound Degradation in the Pesticide Bayleton 500 ec in Sonolysis, Ozonolysis and Sonozolysis with Addition of TiO2-anatase”, EKSAKTA: Berkala Ilmiah Bidang MIPA, 19(2), pp. 70-79. doi: 10.24036/eksakta/vol19-iss2/153.

[27] Zainul, R. (2018, August 16). Determination of the half-life and the quantum yield of $\mathrm{ZnO}$ semiconductor photocatalyst in humic acid. https://doi.org/10.31227/osf.io/e8a9x

[28] Y., \& Zainul, R. (2018, November 18). SILVER SULFATE (Ag2SO4): MOLECULAR ANALYSIS AND ION TRANSPORT. https://doi.org/10.31227/osf.io/n8g9k

[29] Parbuntari, H., Prestica, Y., Gunawan, R., Nurman, M. and Adella, F. (2018) "Preliminary Phytochemical Screening (Qualitative Analysis) of Cacao Leaves 
(Theobroma cacao L.)”, EKSAKTA: Berkala Ilmiah Bidang MIPA, 19(2), pp. 40-45. doi: 10.24036/eksakta/vol19-iss2/142

[30] Tri-Panji, -, Palilingan, Septiany C., Artika, I Made. 2014. OPTIMASI PRODUKSI ENZIMATIS DIASILGLISEROL MELALUI GLISEROLISIS KONTINU [Optimization of Enzymatic Diacylglycerol Production through Continuous Glycerolysis]. Jurnal Teknologi Dan Industri Pangan. Vol 25, No 1

[31] Sarjono, Purbowatiningrum Ria, Ngadiwiyana, Ngadiwiyana, Ismiyarta, Ismiyarta , Prasetya, Nor Basyid A. 2010. AKTIVITAS BUBUK KAYU MANIS (CINNAMOMUM CASSIA) SEBAGAI INHIBITOR ALFA-GLUKOSIDASE. SAINS DAN MATEMATIKA. Volume 18 Issue 2

[32] Nurfadilah, K. K., \& Zainul, R. (2019, February 3). Kalium Nitrat (KNO3): Karakteristik Senyawa dan Transpor Ion. https://doi.org/10.31227/osf.io/dr8ef

[33] Dwynda, I., \& Zainul, R. (2018, November 19). Boric Acid (H3 (BO3):

Recognize The Molecular Interactions in Solutions. https://doi.org/10.31227/osf.io/6wead

[34] Sulastry, Taty . 2009. Analisis Kadar Tanin Ekstrak Air dan Ekstrak Etanol pada Biji Pinang Sirih (Areca Catechu. L). C H E M I C A .Vol 10, No 1

[35] chaidir, z., Zainul, R., Nurakhbari, D., \& Salim, M. (2018, July 29). Optimization of Spirulina Platensis Culture for Antioxidant Production. https://doi.org/10.17605/OSF.IO/FD6E4 